\title{
What is Behind the Figures? Conceptual Mistakes in the Equity Valuations Prepared by Research Analysts in Poland
}

\author{
Pawel Mielcarz, Dmytro Osiichuk*
}

\begin{abstract}
By their nature, corporate valuations are partially built on analysts' opinions, and not only on objective facts. However, it is of primary importance for equity research to be grounded on sound economic theory and existing methodological conventions. Otherwise, an inherent element of subjectivity may degrade into the complete arbitrariness of the assumptions underlying the valuation model. This paper covers conceptual mistakes which may appear in the calculation of the residual value in discounted cash flow valuation models prepared by sell-side equity analysts. In particular, we have analysed some of the essential postulates underlying the estimation of the perpetual growth rate. Our study covering 100 randomly selected investment recommendations prepared by equity research analysts in Poland, shows that these postulates are not adhered to in most cases. Flawed input data translate into the implied company's fundamentals devoid of economic sense. Unrealistic assumptions underlying valuation models question the credibility of investment recommendations and prompt the discussion over the factors shaping the investment decisions of the market participants.
\end{abstract}

Keywords: RONIC; perpetual growth rate; valuation; investment recommendation

\section{Introduction}

Fernandez and Bilan (2007) describe 110 conceptual errors commonly encountered in income-based equity valuation models. They include inconsistencies in cash flow forecasts, mistakes in the calculation of the discount rate, erroneous assumptions regarding a company's capital structure and implied continuous growth rate (e.g., unrealistic exit multiples) etc. This paper expands the list to include the commonly observed mistakes stemming from the lack of adherence to the existing methodological conventions for the discounted cash flow (DCF) models. In particular, we have highlighted the prevalent mishaps in the calculations of continuous growth rates and terminal values, resulting in those figures being in blatant dissonance with the fundamentals of the valued entities. Since in most cases residual value (RV) constitutes a major part of the total enterprise value, the soundness of assumptions underlying the estimation of RV is of primary importance. We have analysed

\footnotetext{
* dr hab. Paweł Mielcarz, Akademia Leona Koźmińskiego w Warszawie, Katedra Finansów, e-mail: pmielcarz@alk. edu.pl, mgr Dmytro Osiichuk, Akademia Leona Koźmińskiego w Warszawie, Katedra Finansów, e-mail: dosiichuk@alk.edu.pl.
} 
the economic theory standing behind the said assumptions and have tried to track whether the essential theoretical postulates are adhered to by Polish equity research analysts.

For the purposes of this study we randomly selected a sample of 100 investment recommendations prepared by the equity research analysts of six major brokerage houses in Poland. We checked whether the estimates of the continuous growth rates for the recommended entities derived from in-depth company fundamentals and accorded with the existing theoretical conventions in the domain of corporate valuation.

\section{Theoretical Assumptions Underlying the Calculation of Residual Value}

The most commonly applied formula for residual value in DCF models is as follows:

$$
R V=\frac{F C F F_{t+1}}{W A C C-g}=\frac{F C F F_{t} \times(1+g)}{W A C C-g}
$$

where:

$R V$ - residual value,

$F C F F_{t}$ - free cash flow for a firm in period $t$, which is usually the end of the explicit forecast period,

WACC - weighted average cost of capital,

$g \quad-$ perpetual growth rate.

Copeland et al. (2010) further deconstructs the formula into:

$$
g=\text { Reinvestment Rate } \times \text { RONIC }
$$

where RONIC - return on new invested capital in the residual period, and

$$
\text { Reinvestment Rate }=\frac{(C A P E X+W C I-D A)}{N O P A T}
$$

or

$$
\text { Reinvestment Rate }=\frac{g}{R O N I C}
$$

where:

CAPEX - capital expenditures in the last year of the explicit forecast,

$W C I$ - working capital investments in the last year of the detailed forecast,

$D A$ - depreciation and amortization in the last year of the explicit forecast,

NOPAT - net operating profit after taxes in the last year of a detailed forecast.

The free cash flow for a firm can be calculated as follows:

$$
F C F F=N O P A T \times(1-\text { Reinvestment Rate })
$$


By plugging equations (2), (3), (4) and (5) into equation (1) we get:

$$
\begin{gathered}
R V=\frac{F C F F_{t} \times(1+g)}{W A C C-g}=\frac{N O P A T \times\left(1-\frac{g}{R O N I C}\right) \times\left(1+\frac{(C A P E X+W C I-D A) \times R O N I C}{N O P A T}\right)}{W A C C-g}= \\
=\frac{N O P A T_{t+1} \times\left(1-\frac{g}{R O N I C}\right)}{W A C C-g}
\end{gathered}
$$

which Copeland et al. (1990) call the key value drivers formula. Formulae (1) and (6) yield identical results. The above formula proves that the value of the perpetual growth rate $g$ should not be estimated independently from the projected company's data, but should rather rely on consistent assumptions regarding the dynamics of RONIC and the reinvestment rate.

In order to be methodologically consistent in the calculation of g, one should start with the assumptions regarding RONIC and the reinvestment rate, which should afterwards serve as inputs for the calculation of $g$ and residual value (Figure 1). However, if the analyst's starts from the perpetual growth rate, further assumptions may lose consistency as shown in Figure 2.

Assumptions

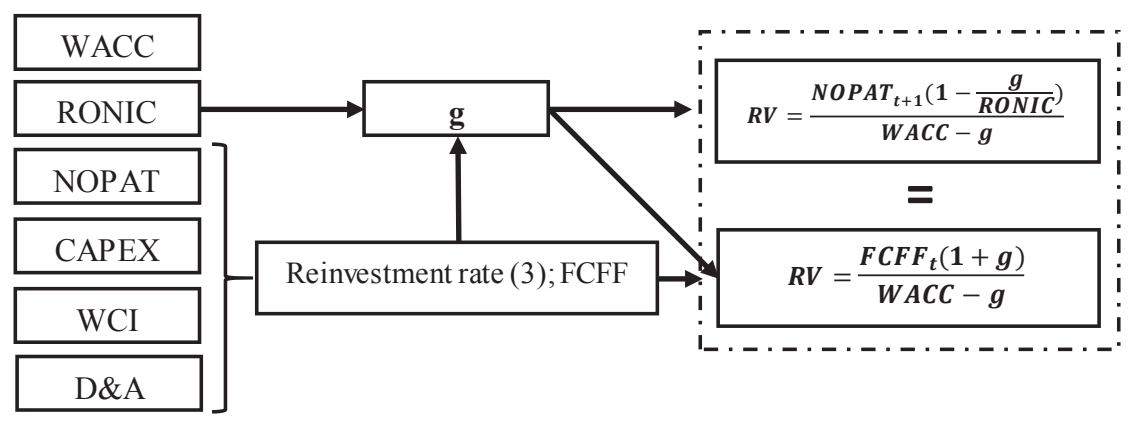

Figure 1. Consistency of the assumptions underlying the valuation model

Source: own study.

Most of the corporate finance and valuation textbooks (Damodaran, 2010; Fernandez, 2015; Ross et al., 2013) cover the problematic area of the estimation of perpetual growth rate. Damodaran (2010) notes that all the inputs for the calculation of the residual value should reasonably describe a company's steady state, which may be sustained indefinitely. The inputs to the calculation of the continuous growth rate may be estimated using both the historical firm-level data and the industry benchmarks. 


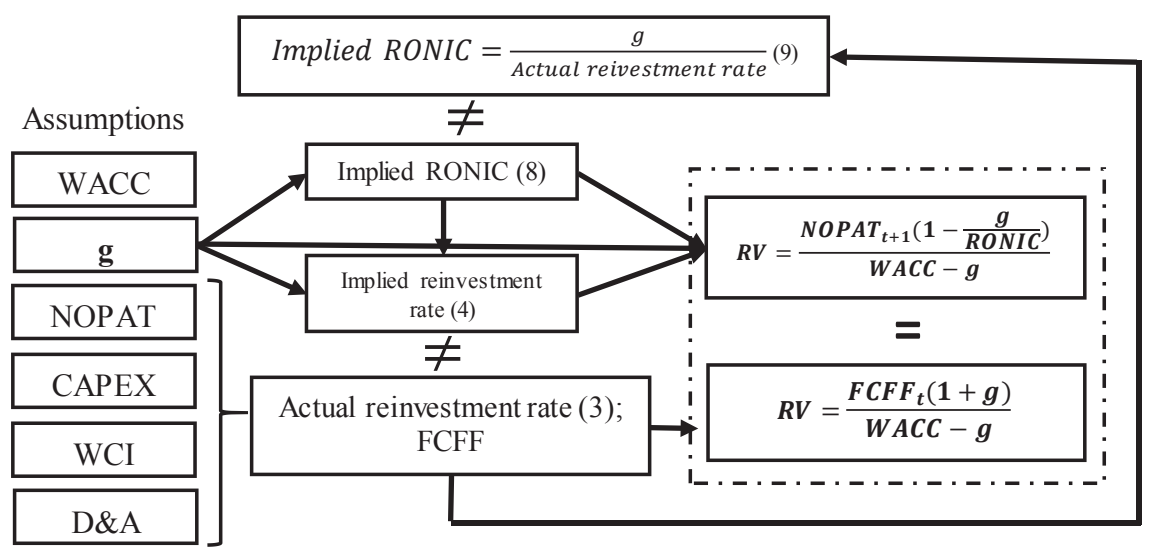

Figure 2. Inconsistent results caused by an inappropriate order of assumptions

Source: own study.

As a company becomes mature, its reinvestment rate should gradually approach the industry averages, unless the company's fundamentals suggest a different pattern.

Return on invested capital (ROIC) in excess of the cost of capital allows the company to create positive economic value-added (EVA):

$$
E V A=(R O I C-W A C C) \times C I
$$

where $C I-$ is the book value of the invested capital.

As a firm expands its operations and increases its market share, the competitive pressure causes a gradual erosion of RONIC. Hence, for the majority of companies, RONIC will gradually approach WACC at the end of the explicit forecast period (Damodaran, 2010; Copeland et al., 2010). If a company's RONIC is considerably higher than WACC in the residual period, a firm is then assumed to possess a well-established competitive advantage, which allows it to create positive value-added infinitely (Mielcarz, Roman, 2012).

For most companies, it is perfectly sound to assume that a higher perpetual growth rate translates into a higher residual value, and therefore, into a higher equity value (E). However, the key determinant, which shapes this relationship and which is often lost from sight, is the RONIC. Basically, there are three options potentially envisaged by the analyst to describe a firm's value creating potential in the residual period:

1. RONIC > WACC. In most cases, the two values will be quite close. Significant difference is possible if a company has an engrained long-lasting competitive advantage (e.g., if the network effect or considerable economies of scale apply). The company with a RONIC exceeding WACC is assumed to create a positive EVA through the entire residual period. 
Under such circumstances, any additional amount of invested capital should increase the total value. However, as the company runs out of attractive investment projects, its reinvestment rate should gradually approach the long-term industry average, which should be sufficient to sustain the company's existing operations and cater for opportunities of organic growth (usually it corresponds to the growth of the market, which the company shares with its rivals). Therefore, this inequality should not hold for most companies, as the increasing competition exercises a downward pressure on the RONIC (Damodaran, 1994). The transmission mechanism is as follows:

$$
R O I C>W A C C \Rightarrow(C A P E X \uparrow \text { or } W C I \uparrow) \Rightarrow \text { Reinvestment Rate } \uparrow \Rightarrow g \uparrow \Rightarrow R V \uparrow \Rightarrow E \uparrow .
$$

2. $R O N I C=W A C C$. Additional amounts of invested capital create no value-added. Increased investment translates into an increased reinvestment rate, which, in turn, contributes to the increase of the perpetual growth rate. However, the total value does not change. Hence, investments and growth rate become value neutral. The relationship may be summarized as follows:

$$
R O N I C=W A C C \Rightarrow(C A P E X \uparrow \text { or } W C I \uparrow) \Rightarrow \text { Reinvestment Rate } \uparrow \Rightarrow g \uparrow \Rightarrow R V=\text { const. }
$$

It appears to be the most widespread scenario as the majority of companies are not able to secure a long-term competitive advantage allowing them to generate RONIC in excess of WACC in perpetuity.

3. RONIC < WACC. This case appears to be the least likely. A company is assumed to create a negative economic value-added through the entire residual period. The shareholder value is assumed to be gradually wasted through unproductive investments. This situation is not sustainable: it contradicts the highest and best use assumption (HBU) endorsed by the International Valuation Standards and International Financial Reporting Standard 13 (Mielcarz, Wnuczak, 2011). The shareholders will try to remedy the situation by either replacing the company's management (if the source of inefficiency resides in managerial practices) or by withdrawing funds and discontinuing value-destroying operations. Hence, despite its positive contribution to the increase of the perpetual growth rate, any additional investments in such settings will result in more value destruction as more and more capital will be put to an unproductive use. The relationship may be summarized as follows:

$$
\text { RONIC }<W A C C \Rightarrow(C A P E X \uparrow \text { or } W C I \uparrow) \Rightarrow \text { Reinvestment Rate } \uparrow \Rightarrow g \uparrow \Rightarrow R V \downarrow \Rightarrow \mathrm{E} \downarrow \text {. }
$$

To sum up, the calculation of the continuous growth rate should be preceded with a careful analysis of the company's competitive position, its ability to resist competitive pressure in the long-term perspective, and its sustainable reinvestment policy which may apply in the residual period. 


\section{Mistakes Discovered in Equity Valuation Models}

In order to check whether the aforementioned theoretical postulates are adhered to in practice, we collected a sample of 100 investment recommendations prepared by the equity research analysts of 6 major brokerage houses (encoded by letters A-F) in Poland in 2015 (last quarter) and 2016. The recommendations are publicly available on the webpage www. bankier.pl. All of them feature DCF valuations based on FCFF methodology. Table 2 summarizes the primary data retrieved from the recommendations. By rearranging formula (2) and (6) we get the implied value of RONIC:

$$
\begin{gathered}
R O N I C=\frac{N O P A T_{t+1} \times g}{N O P A T_{t+1}-R V(W A C C-g)} \\
R O N I C=\frac{g}{\text { Actual reinvestment rate }}
\end{gathered}
$$

It should be emphasized, that formulae (8) and (9) do not yield the same result if the inputs are misaligned. Hence, changing the order of the assumptions may break the consistency of the valuation inputs. All further comments refer to RONIC calculated relying on formula (8).

We also retrieved the data for the companies' investment policy in the residual period: CAPEX, working capital investment and depreciation. Using formula (3) we calculated the actual reinvestment rates assumed by the analysts. By plugging the values of $g$ and Implied RONIC into formula (4) we can calculate the implied reinvestment rate, which may not be equal to the actual reinvestment rate featuring in the recommendations if the equalities (2)-(5) do not hold.

In 99 recommendations the perpetual growth rate is non-negative (in one recommendation $g=0 \%$ and in another one $g=-2 \%$ ). In 64 recommendations RONIC $>$ WACC, in 36 recommendations RONIC $<$ WACC. Hence, in $36 \%$ of cases the analyst implicitly assumed that a company would not discontinue its operations despite destroying shareholder value. In the vast majority of the analysed recommendations, the implied RONICs are not justifiable being either considerably higher than the WACC and most probably currently applicable ROIC (which is unrealistic in the residual period) or significantly lower than the applicable hurdle rate.

All the presented conceptual mistakes are summarized in Table 1.

In 19 cases out of 100 the implied RONIC is below zero, which is devoid of economic sense and point to the fact that the perpetual growth rate was chosen without reference to the company's fundamentals.

In 32 recommendations the FCFF forecasts suggest that the companies will keep on investing in the residual period despite their RONIC being below WACC. In 6 recommendations the companies have negative net investments in the residual period; in 3 recommendations 
out of these 6 the companies disinvest despite having their RONIC considerably higher than WACC. Negative reinvestment rate implies the gradual reduction of the company's fixed assets and winding up of the operations (Damodaran, 2010).

\section{Table 1}

Summary of the conceptual mistakes encountered in the analysed sample of recommendations

\begin{tabular}{|c|c|c|c|c|c|}
\hline \multicolumn{6}{|c|}{ Conceptual errors embedded in the implied RONIC calculated using formula (8) or (9) } \\
\hline $\begin{array}{l}\text { Descrip- } \\
\text { tion of the } \\
\text { mistake }\end{array}$ & $\begin{array}{l}\text { Abnormally high } \\
\text { RONIC (significantly } \\
\text { higher than WACC) } \\
\text { without any proper } \\
\text { justification }\end{array}$ & $\begin{array}{l}\text { RONIC }< \\
\text { WACC } \\
\text { and RONIC } \geq 0\end{array}$ & RONIC $<0$ & $\begin{array}{l}\text { RONIC }> \\
\text { WACC when } \\
\mathrm{g}<0 \text { and Actual } \\
\text { reinvestment } \\
\text { rate }<0\end{array}$ & $\begin{array}{l}\text { RONIC }=0 \% \text { implied } \\
\text { in } \mathrm{g}=0 \% \text { under the } \\
\text { assumption of Actual } \\
\text { reinvestment rate }<0\end{array}$ \\
\hline $\begin{array}{l}\text { Implied } \\
\text { assump- } \\
\text { tion }\end{array}$ & $\begin{array}{l}\text { The company has } \\
\text { a strong, sustainable } \\
\text { perpetual competitive } \\
\text { advantage and signi- } \\
\text { ficantly outperforms } \\
\text { its peers }\end{array}$ & $\begin{array}{l}\text { The company } \\
\text { undertakes } \\
\text { negative-NPV } \\
\text { projects and } \\
\text { creates negative } \\
\text { EVA through the } \\
\text { residual period }\end{array}$ & $\begin{array}{l}\text { The company } \\
\text { destroys sha- } \\
\text { reholder value } \\
\text { through the } \\
\text { entire residual } \\
\text { period and the } \\
\text { owners knowin- } \\
\text { gly accept it }\end{array}$ & $\begin{array}{l}\text { The company } \\
\text { has attractive } \\
\text { investment } \\
\text { projects but disi- } \\
\text { nvests, causing } \\
\text { the cash flows to } \\
\text { shrink }\end{array}$ & $\begin{array}{l}\text { RONIC }=0 \%<\text { WACC, } \\
\text { hence, the company } \\
\text { is assumed to destroy } \\
\text { shareholder value in the } \\
\text { residual period. Mathe- } \\
\text { matical implication of } \\
\text { formula ( } 2 \text { ). Additio- } \\
\text { nally, the company } \\
\text { disinvests }\end{array}$ \\
\hline $\begin{array}{l}\text { Number of } \\
\text { mistakes }\end{array}$ & $\begin{array}{l}48(\text { RONIC }>2 \times \\
\text { WACC) }\end{array}$ & 17 & 19 & 1 & 1 \\
\hline \multicolumn{6}{|c|}{ Conceptual errors embedded in the actual reinvestment rate (retrieved from recommendations) } \\
\hline $\begin{array}{l}\text { Descrip- } \\
\text { tion of the } \\
\text { mistake }\end{array}$ & $\begin{array}{l}\text { Reinvestment Rate } \neq \\
0 \text { linked with } g=0 \%\end{array}$ & $\begin{array}{l}\text { Reinvestment } \\
\text { rate }<0 \text { linked } \\
\text { with } g \geq 0 \%\end{array}$ & $\begin{array}{l}\text { Reinvestment } \\
\text { rate }>0 \text { linked } \\
\text { with RONIC }< \\
\text { WACC }\end{array}$ & $\begin{array}{l}\text { Reinvestment } \\
\text { rate }<0 \text { linked } \\
\text { with RONIC }> \\
\text { WACC }\end{array}$ & $\begin{array}{l}\text { Reinvestment rate }=0 \\
\text { linked with } g>0 \text { and } \\
\text { unjustifiable RONIC } \\
\text { (excessively high or } \\
\text { negative) }\end{array}$ \\
\hline $\begin{array}{l}\text { Implied } \\
\text { assump- } \\
\text { tion }\end{array}$ & $\begin{array}{l}\text { The company } \\
\text { perpetually executes } \\
\text { negative-NPV projects } \\
\text { as the implied RONIC } \\
=0 \%<\text { WACC }\end{array}$ & $\begin{array}{l}\text { Despite perpetu- } \\
\text { al disinvestment } \\
\text { (which even- } \\
\text { tually exhausts } \\
\text { the stock of } \\
\text { operating assets) } \\
\text { the company is } \\
\text { able to increase } \\
\text { generated cash } \\
\text { flows }\end{array}$ & $\begin{array}{l}\text { The company } \\
\text { invests despite } \\
\text { generating nega- } \\
\text { tive EVA from } \\
\text { the incremental } \\
\text { invested capital. } \\
\text { Intentional } \\
\text { destruction of } \\
\text { shareholder } \\
\text { value }\end{array}$ & $\begin{array}{l}\text { The company di- } \\
\text { sinvests despite } \\
\text { having a stock } \\
\text { of attractive } \\
\text { investment pro- } \\
\text { jects generating } \\
\text { a high rate of } \\
\text { return }\end{array}$ & $\begin{array}{l}\text { Zero reinvestment rate } \\
\text { implies g }=0 \% \text { (formula } \\
\text { 2). The company either } \\
\text { 1) does not invest } \\
\text { despite having attractive } \\
\text { opportunities (high } \\
\text { RONIC); or 2) maintains } \\
\text { operations despite de- } \\
\text { stroying value (negative } \\
\text { RONIC) }\end{array}$ \\
\hline $\begin{array}{l}\text { Number of } \\
\text { mistakes }\end{array}$ & 1 & 4 & 32 & 3 & 4 \\
\hline
\end{tabular}

Source: own elaboration.

In 31 recommendations CAPEX is assumed to be equal to depreciation in the residual period. The positive reinvestment rate is secured by ever increasing working capital investments.

In four recommendations the actual reinvestment rate is zero. In one of them the implied RONIC is considerably below zero and makes no sound economic sense, in the other three the implied RONIC is unjustifiably higher than WACC. 
We deliberately included several recommendations prepared for the same entities for the same period prepared by different brokerage houses. Take the example of recommendations No. 3 (Table 2) and No. 27 prepared for LPP SA by the institutions G and F respectively: 1) for No. 3 the implied RONIC (formula 8 ) is negative but the company is assumed to keep investing in the residual period; 2) in No. 27 the implied RONIC is below WACC, but the authors of the recommendations assume (through the reinvestment rate) that the company invests heavily in value-destroying operations in the residual period. The recommendations do not even closely accord with any of the implied company's fundamentals.

\section{Table 2}

Summary of the research

\begin{tabular}{|c|c|c|c|c|c|c|c|c|c|c|}
\hline No & Issuer & $\begin{array}{l}\text { Recom- } \\
\text { mended } \\
\text { Entity }\end{array}$ & $\begin{array}{l}\text { Recom- } \\
\text { menda- } \\
\text { tion }\end{array}$ & $\begin{array}{l}\mathrm{g} \\
(\%)\end{array}$ & $\begin{array}{l}\text { NO- } \\
\text { PAT } \times \\
(1+g)\end{array}$ & RV & $\begin{array}{l}\text { WACC } \\
(\%)\end{array}$ & $\begin{array}{l}\text { Implied } \\
\text { RONIC (8) } \\
(\%)\end{array}$ & $\begin{array}{l}\text { Actual Re- } \\
\text { investment } \\
\text { Rate (3) } \\
(\%)\end{array}$ & $\begin{array}{l}\text { Implied } \\
\text { RONIC (9) } \\
(\%)\end{array}$ \\
\hline 1 & 2 & 3 & 4 & 5 & 6 & 7 & 8 & 9 & 10 & 11 \\
\hline 1 & $\mathrm{~A}$ & CCC SA & Hold & 1.50 & 735.9 & 10,603 & 7.40 & 10.0 & 14.5 & 10.4 \\
\hline 2 & $\mathrm{G}$ & CCC SA & Hold & 3.00 & 577.1 & 9,783 & 7.90 & 17.7 & 15.2 & 19.7 \\
\hline 3 & G & LPP SA & Sell & 2,00 & 686.7 & 13,200 & 8,00 & -13.0 & 16.8 & 11.9 \\
\hline 4 & $\mathrm{C}$ & KGHM & Buy & 1.50 & $2,773.0$ & 31,815 & 9.00 & 10.8 & 42.8 & 3.5 \\
\hline 5 & $\mathrm{~B}$ & ATM Grupa & Buy & 2.00 & 18.2 & 255 & 8.70 & 33.1 & 25.3 & 7.9 \\
\hline 6 & $\mathrm{~B}$ & Śnieżka & Buy & 2.00 & 68.6 & 940 & 9.00 & 48.0 & 8.2 & 24.5 \\
\hline 7 & $\mathrm{~B}$ & Groclin & Buy & 2.00 & 30.5 & 378 & 8.80 & 12.7 & 17.7 & 11.3 \\
\hline 8 & $\mathrm{~B}$ & Vistula & Buy & 2.00 & 68.6 & 985 & 8.70 & 51.5 & 4.2 & 48.1 \\
\hline 9 & $\mathrm{~B}$ & Orbis & Buy & 2.50 & 275.2 & 4,438 & 8.50 & 77.0 & 6.7 & 37.3 \\
\hline 10 & $\mathrm{C}$ & Pekabex & Hold & 1.00 & 29.3 & 372 & 8.50 & 20.5 & 5.2 & 19.3 \\
\hline 11 & $\mathrm{C}$ & Apator & Hold & 0.50 & 78.6 & 1,119 & 7.40 & 28.9 & 2.0 & 24.4 \\
\hline 12 & $\mathrm{~B}$ & PKN Orlen & Buy & 1.00 & 3.9 & 43 & 10.00 & 84.9 & 1.8 & 55.6 \\
\hline 13 & $\mathrm{~B}$ & PCC Rokita & Hold & 0.00 & 147.6 & 1,856 & 7.70 & 0.0 & -0.3 & 0.0 \\
\hline 14 & B & MFO & Buy & 1.00 & 21.1 & 212 & 9.30 & 6.0 & 24.4 & 4.1 \\
\hline 15 & $\mathrm{D}$ & Alumetal & Hold & 2.00 & 814 & 1,196 & 8.50 & 44.3 & 4.5 & 44.3 \\
\hline 16 & $\mathrm{C}$ & PKP Cargo & Sell & 1.50 & 266.0 & 4,101 & 6.70 & 7.6 & 20.3 & 7.4 \\
\hline 17 & $\mathrm{~B}$ & LOTOS & Buy & 1.00 & $1,034.5$ & 12,050 & 9.50 & 100.8 & 0.3 & 349.7 \\
\hline 18 & $\mathrm{C}$ & ROBYG & Buy & 1.00 & 64.1 & 1,018 & 7.50 & -32.0 & 1.4 & 70.6 \\
\hline 19 & B & $\begin{array}{l}\text { Dom Deve- } \\
\text { lopment }\end{array}$ & Hold & 1.00 & 90.3 & 1,436 & 7.50 & -29.6 & 14.4 & 6.9 \\
\hline 20 & $\mathrm{C}$ & Budimex & Hold & 2.00 & 222.7 & 3,823 & 8.30 & -24.5 & 6.9 & 29.1 \\
\hline 21 & $\mathrm{C}$ & JSW & Buy & 1.50 & 815.1 & 6,771 & 10.00 & 5.1 & 60.3 & 2.5 \\
\hline 22 & $\mathrm{E}$ & $\begin{array}{l}\text { Mercator } \\
\text { Medical }\end{array}$ & Buy & 1.00 & 35.0 & 404 & 9.80 & -63.4 & 0.0 & $\mathrm{n} / \mathrm{a}$ \\
\hline 23 & $\mathrm{C}$ & WPH & Buy & 3.00 & 159.5 & 2,310 & 9,60 & 67.3 & 1.0 & 309.8 \\
\hline 24 & B & $\begin{array}{l}\text { Mostostal } \\
\text { Zabrze }\end{array}$ & Buy & 1.00 & 13.6 & 160 & 9.00 & 16.5 & 7.4 & 13.5 \\
\hline 25 & $\mathrm{~B}$ & COGNOR & Buy & 1.00 & 81.6 & 737 & 12.40 & -34.0 & 10.4 & 9.6 \\
\hline 26 & $\mathrm{~F}$ & CCC SA & Hold & 3.00 & 849.8 & 12,488 & 7.30 & 8.2 & 27.5 & 10.9 \\
\hline 27 & $\mathrm{~F}$ & LPP SA & Hold & 2.50 & $1,081.4$ & 13,318 & 7.60 & 6.7 & 24.0 & 10.4 \\
\hline
\end{tabular}


What is Behind the Figures? Conceptual Mistakes in the Equity Valuations Prepared...

\begin{tabular}{|c|c|c|c|c|c|c|c|c|c|c|}
\hline 1 & 2 & 3 & 4 & 5 & 6 & 7 & 8 & 9 & 10 & 11 \\
\hline 28 & $\mathrm{~F}$ & $\begin{array}{l}\text { Vistula } \\
\text { Group }\end{array}$ & Buy & 2.00 & 70.9 & 1,004 & 7.30 & 8.0 & 15.8 & 12.6 \\
\hline 29 & B & FORTE & Sell & 2.00 & 210.7 & 2,619 & 9.00 & 15.4 & 11.2 & 17.8 \\
\hline 30 & $\mathrm{E}$ & Archicom & Buy & 1.00 & 64.4 & 700 & 8.70 & 6.1 & 11.0 & 9.1 \\
\hline 31 & $\mathrm{~B}$ & $\begin{array}{l}\text { Cyfrowy } \\
\text { Polsat }\end{array}$ & Buy & 1.00 & $2,217.0$ & 28,886 & 8.30 & 20.5 & 5.3 & 18.9 \\
\hline 32 & B & GPW & Buy & 1.50 & 125.9 & 1,739 & 8.60 & 79.0 & 6.5 & 23.3 \\
\hline 33 & $\mathrm{C}$ & Bogdanka & Hold & 1.00 & 194.6 & 2,610 & 8.20 & 29.0 & -11.4 & -8.8 \\
\hline 34 & $\mathrm{C}$ & JSW & Buy & 1.00 & 723.7 & 4,762 & 10.50 & 2.7 & 39.9 & 2.5 \\
\hline 35 & $\mathrm{C}$ & Kęty & Buy & 2.00 & 310.4 & 4,538 & 8.30 & 25.3 & 5.1 & 39.5 \\
\hline 36 & $\mathrm{C}$ & $\mathrm{AB}$ & Hold & 1.00 & 81.5 & 1,046 & 8.60 & 40.6 & 9.4 & 10.6 \\
\hline 37 & B & COGNOR & Buy & 1.00 & 81.2 & 753 & 12.10 & -34.9 & 10.2 & 9.8 \\
\hline 38 & $\mathrm{C}$ & Eurocash & Buy & 2.00 & 485.0 & 8,341 & 7.90 & -136.1 & 7.1 & 28.1 \\
\hline 39 & $\mathrm{C}$ & Ciech & Hold & 1.00 & 309.0 & 5,176 & 6.80 & 35.4 & 16.1 & 6.2 \\
\hline 40 & $\mathrm{C}$ & KGHM & Buy & 1.50 & $2,289.1$ & 31,476 & 8.20 & 19.1 & 66.2 & 2.3 \\
\hline 41 & $\mathrm{C}$ & AmRest & Buy & 3.00 & 395.1 & 8,859 & 6.90 & 23.9 & 33.9 & 8.8 \\
\hline 42 & $\mathrm{E}$ & $\begin{array}{l}\text { The Farm } \\
51\end{array}$ & Buy & 2.00 & 6.1 & 90 & 8.80 & 1285.7 & 0.0 & $\mathrm{n} / \mathrm{a}$ \\
\hline 43 & $\mathrm{~B}$ & COMP & Buy & 2.00 & 52.3 & 711 & 9.00 & 40.9 & 4.9 & 41.0 \\
\hline 44 & $\mathrm{~B}$ & $\begin{array}{l}\mathrm{CO}- \\
\mathrm{MARCH}\end{array}$ & Buy & 2.00 & 132.9 & 1,761 & 9.00 & 27.6 & 19.6 & 10.2 \\
\hline 45 & $\mathrm{~F}$ & $\begin{array}{l}\text { ZM Henryk } \\
\text { Kania }\end{array}$ & Buy & 1.50 & 84.8 & 868 & 8.50 & 5.3 & 27.5 & 5.4 \\
\hline 46 & $\mathrm{C}$ & $\begin{array}{l}\text { Pfleiderer } \\
\text { Grajewo }\end{array}$ & Hold & 1.00 & 55.3 & 852 & 7.30 & 33.1 & 2.7 & 36.5 \\
\hline 47 & $\mathrm{C}$ & PGNIG & Buy & 1.00 & $2,483.6$ & 38,347 & 7.80 & -20.0 & 28.2 & 3.5 \\
\hline 48 & $\mathrm{C}$ & $\begin{array}{l}\text { Grupa } \\
\text { Azoty }\end{array}$ & Hold & 1.00 & 889.0 & 12,456 & 8.00 & 52.1 & 7.1 & 14.1 \\
\hline 49 & $\mathrm{~B}$ & PKP Cargo & Buy & 1.00 & 295.7 & 3,689 & 9.00 & 499.5 & 1.2 & 81.3 \\
\hline 50 & $\mathrm{C}$ & Synthos & Buy & 1.00 & 562.9 & 8,010 & 8.10 & -96.4 & 16.8 & 6.0 \\
\hline 51 & $\mathrm{~B}$ & $\begin{array}{l}\text { Arctic } \\
\text { Paper }\end{array}$ & Buy & -2.00 & 31.2 & 295 & 9.00 & 47.7 & -4.1 & 48.9 \\
\hline 52 & $\mathrm{C}$ & Tauron & Hold & 1.00 & $1,952.3$ & 24,003 & 6.90 & 3.6 & 28.0 & 3.6 \\
\hline 53 & $\mathrm{~B}$ & $\mathrm{CIECH}$ & Buy & 1.00 & 446.4 & 5,535 & 9.00 & 122.8 & 0.8 & 119.5 \\
\hline 54 & $\mathrm{C}$ & Otmuchów & Hold & 1.00 & 6.9 & 98 & 7.80 & 34.6 & 27.9 & 3.6 \\
\hline 55 & B & Kęty & Buy & 2.00 & 348.1 & 4,495 & 9.00 & 20.8 & 10.0 & 20.0 \\
\hline 56 & $\mathrm{E}$ & $\begin{array}{l}\text { VIGO } \\
\text { System }\end{array}$ & Buy & 1.00 & 19.7 & 223 & 9.30 & 16.8 & 5.6 & 17.7 \\
\hline 57 & $\mathrm{C}$ & Enea & Hold & 1.00 & $1,478.9$ & 15,385 & 6.90 & 2.6 & 38.7 & 2.6 \\
\hline 58 & $\mathrm{E}$ & Archicom & Buy & 1.00 & 54.9 & 612 & 8.50 & 6.1 & 9.2 & 10.9 \\
\hline 59 & $\mathrm{C}$ & CEZ & Buy & 100 & 20,078 & 497,283 & 5.00 & 107.1 & 1.0 & 103.0 \\
\hline 60 & $\mathrm{C}$ & Energa & Hold & 1,00 & $1,129.6$ & 13,709 & 6.80 & 3.4 & 29.4 & 3.4 \\
\hline 61 & $\mathrm{C}$ & PGE & Buy & 1.00 & $3,674.9$ & 56,682 & 7.50 & -388.7 & -0.5 & -214.0 \\
\hline 62 & B & Stalprofil & Buy & 2.00 & 37.4 & 500 & 8.80 & 21.8 & 9.0 & 22.2 \\
\hline 63 & B & $\begin{array}{l}\text { Dom Deve- } \\
\text { lopment }\end{array}$ & Hold & 1.00 & 123.2 & 1,550 & 8.09 & 9.3 & 10.6 & 9.5 \\
\hline 64 & B & Robyg & Buy & 1.00 & 95.1 & 1,198 & 8.20 & 10.7 & 6.8 & 14.7 \\
\hline 65 & $\mathrm{~B}$ & Budimex & Sell & 1.00 & 236.1 & 2,951 & 9.00 & 6945.2 & 1.6 & 63.2 \\
\hline 66 & $\mathrm{~B}$ & Wasko & Buy & 1.00 & 17.5 & 214 & 9.00 & 53.1 & 7.5 & 13.3 \\
\hline
\end{tabular}




\begin{tabular}{|c|c|c|c|c|c|c|c|c|c|c|}
\hline 1 & 2 & 3 & 4 & 5 & 6 & 7 & 8 & 9 & 10 & 11 \\
\hline 67 & $\mathrm{E}$ & $\begin{array}{l}\text { Soho Deve- } \\
\text { lopment }\end{array}$ & Buy & 1.00 & 16.5 & 166 & 9.00 & 5.2 & 276.1 & 0.4 \\
\hline 68 & $\mathrm{C}$ & ZPUE & Hold & 0.50 & 53.3 & 752 & 7.40 & 19.0 & 3.0 & 16.6 \\
\hline 69 & $\mathrm{~B}$ & Bytom & Sell & 1.00 & 24.6 & 303 & 9.00 & 57.6 & 1.6 & 61.0 \\
\hline 70 & $\mathrm{E}$ & $\begin{array}{l}\text { JHM Deve- } \\
\text { lopment }\end{array}$ & Buy & 0.50 & 16.8 & 155 & 9.50 & 3.0 & 57.5 & 0.9 \\
\hline 71 & $E$ & Impel & Buy & 2.20 & 52.6 & 715 & 9.40 & 103.3 & 0.0 & $\mathrm{n} / \mathrm{a}$ \\
\hline 72 & $\mathrm{C}$ & Action & Sell & 1.00 & 43.8 & 607 & 7.50 & 10.0 & 9.4 & 10.6 \\
\hline 73 & $\mathrm{~B}$ & Stalprodukt & Buy & 2.00 & 152.3 & 2,087 & 8.80 & 29.4 & 9.4 & 21.3 \\
\hline 74 & $\mathrm{~B}$ & Forte & Buy & 2.00 & 190.7 & 2,429 & 9.00 & 18.4 & 8.7 & 23.1 \\
\hline 75 & $\mathrm{~B}$ & ATM Grupa & Hold & 2.00 & 18.8 & 299 & 8.90 & -20.4 & 24.5 & 8.2 \\
\hline 76 & $\mathrm{~B}$ & Selena FM & Buy & 1.00 & 56.9 & 597 & 10.00 & 18.1 & 6.0 & 16.6 \\
\hline 77 & $\mathrm{C}$ & Action & Buy & 1.00 & 66.1 & 805 & 8.50 & 11.6 & 7.0 & 14.2 \\
\hline 78 & $\mathrm{C}$ & $\mathrm{AB}$ & Buy & 1.00 & 84.9 & 1132 & 8.30 & 36.4 & 9.6 & 10.4 \\
\hline 79 & $\mathrm{C}$ & Eurocash & Buy & 2.00 & 579.2 & 9,806 & 8.10 & -60.9 & 6.2 & 32.4 \\
\hline 80 & $\mathrm{C}$ & Emperia & Buy & 2.00 & 87.8 & 1,001 & 8.20 & 6.8 & 41.8 & 4.8 \\
\hline 81 & $\mathrm{E}$ & $\begin{array}{l}\text { VIGO } \\
\text { System }\end{array}$ & Buy & 2.00 & 15.4 & 190 & 9.50 & 27.0 & 5.3 & 37.8 \\
\hline 82 & $\mathrm{E}$ & $\begin{array}{l}\text { OT Logi- } \\
\text { stics }\end{array}$ & Buy & 1.00 & 39.4 & 451 & 9.70 & 222.1 & 0.0 & $\mathrm{n} / \mathrm{a}$ \\
\hline 83 & $\mathrm{~B}$ & Qumak & Sell & 1.00 & 11.8 & 120 & 8.70 & 4.6 & 24.8 & 4.0 \\
\hline 84 & $\mathrm{~B}$ & Bytom & Sell & 1.00 & 22.3 & 275 & 9.00 & 61.8 & 1.8 & 55.3 \\
\hline 85 & $\mathrm{C}$ & Pekabex & Hold & 1.00 & 29.6 & 357 & 9.00 & 28.4 & 2.7 & 36.6 \\
\hline 86 & $\mathrm{C}$ & Synthos & Buy & 1.00 & 590.9 & 8,575 & 8.00 & -62.7 & 22.9 & 4.4 \\
\hline 87 & $\mathrm{C}$ & AmRest & Buy & 3.00 & 342.2 & 62,79 & 6.60 & 8.8 & 53.9 & 5.6 \\
\hline 88 & $\mathrm{C}$ & $\begin{array}{l}\text { Grupa } \\
\text { Azoty }\end{array}$ & Sell & 1.00 & 854.3 & 11,368 & 8.90 & -19.5 & 5.7 & 17.4 \\
\hline 89 & $\mathrm{~B}$ & GPW & Buy & 1.50 & 135.0 & 1,875 & 8.60 & 108.3 & 1.5 & 99.8 \\
\hline 90 & $\mathrm{C}$ & PGNIG & Hold & 1.00 & $2,468.4$ & 36,808 & 7.60 & 63.1 & 28.4 & 3.5 \\
\hline 91 & $\mathrm{C}$ & Forte & Buy & 1.50 & 165.0 & 2252 & 8.20 & 17.5 & 7.4 & 20.3 \\
\hline 92 & B & PGNiG & Sell & 1.00 & 2.3 & 28 & 9.00 & -776.7 & 12.1 & 8.3 \\
\hline 93 & $\mathrm{E}$ & Polmed & Buy & 1.00 & 8.3 & 100 & 8.80 & 17.2 & 4.9 & 20.5 \\
\hline 94 & $\mathrm{~B}$ & Selvita & Hold & 2.00 & 13.5 & 209 & 8.30 & 94.7 & -0.8 & -264.0 \\
\hline 95 & $\mathrm{C}$ & Budimex & Buy & 2.00 & 239.6 & 4,164 & 8.20 & -25.8 & 7.2 & 27.6 \\
\hline 96 & $\mathrm{C}$ & Apator & Hold & 0.50 & 87.4 & 1,171 & 7.90 & 54.9 & 1.8 & 27.2 \\
\hline 97 & $\mathrm{C}$ & CEZ & Hold & 1.00 & 20,262 & 472,829 & 5.40 & -37.4 & -1.2 & -80.1 \\
\hline 98 & $\mathrm{C}$ & Enea & Buy & 1.00 & $1,101.2$ & 14,775 & 6.40 & 3.6 & 27.9 & 3.6 \\
\hline 99 & $\mathrm{C}$ & Energa & Buy & 1.00 & $1,005.5$ & 5,279 & 6.00 & 1.4 & 30.6 & 3.3 \\
\hline 100 & $\mathrm{C}$ & PGE & Buy & 1.00 & $2,974.5$ & 55,436 & 6.90 & -10.0 & 6.7 & 14.9 \\
\hline
\end{tabular}

Source: own elaboration.

Special attention should be drawn to the recommendations with the perpetual growth rate of zero. Formula (2) implies that such an outcome is possible only in two cases: 1) the reinvestment rate equals zero; 2) the implied RONIC equals zero (which would make no sound sense because RONIC would be considerably below WACC). There is only one such recommendation in the sample (No. 13 prepared by the analyst from brokerage house B). 
The implied RONIC equals zero (due to the construction of the formula). Based on the primary data retrieved from the recommendation, the calculated reinvestment rate is negative. Hence, in our opinion this recommendation contains two very serious conceptual mistakes: 1) it is assumed that the company invests at the rate below the alternative cost of capital in the residual period, which violates the fair value estimation principles; 2) it is assumed that the company will disinvest in the residual period, which makes no sense from the standpoint of the 'going concern' assumption: the company will ultimately liquidate its fixed assets and will be forced to discontinue its operations.

Another curious case involves negative perpetual growth rates. We have only one such recommendation in the sample prepared by institution B for Arctic Paper SA (recommendation No. 51). The analyst assumed a continuous growth rate of $(-2 \%)$, which is explained by the forecasted stagnation of revenues, the decay in profit margins and gradually shrinking market. In line with the traced line of reasoning the analyst assumed that the company would disinvest in the residual period in order to accommodate market shrinkage. However, the implied RONIC is 5 times higher than the cost of capital, which deprives the figures of economic sense. We have a decaying company which envisages disinvestments in the face of industry restructuring, but which can potentially attain a huge return on new investments. For it to make sound economic sense, the disinvestments should take place due to RONIC being below the required rate of return (RONIC $<$ WACC). It would justify negative reinvestment and would allow accommodating a negative continuous growth rate. It also perfectly accords with the decaying profit margins.

Clearly, these recommendations represent anecdotal evidence, but they may be indicative of a pervasive issue undermining the credibility of investment recommendations. In our opinion, there may be a serious misconception underlying the mistakes encountered in the analysed recommendations. There might exist confusion regarding the principal factor contributing to the terminal value. The culprits are perpetual growth rate and RONIC. The analysts may assume that in order to make the growth value neutral in the residual period, one has to assume a zero perpetual growth rate, which is correct only if the reinvestment rate is equal to 0 (RONIC $=0$ does not make sense as it is lower than WACC causing the company to disinvest and discontinue its operations). And zero reinvestment rate would make sense only if ROIC=WACC, which would make any incremental investment value neutral. Hence, zero growth rate should be consistent with the reinvestment rate incorporated into the cash flow forecast.

Our findings strongly suggest that the continuous growth rates appearing in the investment recommendations may be estimated without paying due attention to the company's in-depth fundamentals. The implied RONIC rates and reinvestment rates are often inconsistent with the theoretical pillars underlying corporate valuation modelling. This observation should have important practical implications for it may pinpoint the areas requiring remedial action on the part of the recommendation issuers. 


\section{In-Depth Fundamentals, Market Sentiment or Pure Price Pressure?}

The findings presented in the paper may prompt a discussion about the driving force shaping the influence of the investment recommendations on the abnormal returns generated by the recommended stocks.

The profit-making investment strategies based on recommendations have been studied in a vast body of research (Barber et al., 2001; Green, 2006; Zaremba, Konieczka, 2015, Mielcarz et al. (2007) and Mielcarz, Podgórski (2008). However, the factors underlying the influence of recommendations on abnormal returns of the recommended stocks are subject to active debate. Mielcarz (2016) formulated three hypotheses, which may clarify the issue: 1) the influence of the recommendations on the abnormal rates of return may stem from the contents of the recommendations; 2) the mere fact of issuance of the recommendation may cause the effect of price pressure, which has nothing to do with the contents (Womack, 1992); 3) the influence may derive from the factors not related to the contents (Barber, Odean, 2008).

The prevalence of methodologically inaccurate valuation models not grounded on solid economic theory may speak in favour of the price pressure effect unrelated to the contents of the recommendation. The investors may take their decisions basing them solely on the bottom line of the valuation model without taking due care of its methodological correctness. It may appear that recommendations reflect only the currently prevailing market sentiment of financial analysts regarding a particular stock without paying sufficient attention to the fundamentals.

\section{Concluding Remarks}

The paper draws attention to the conceptual mistakes which may disqualify the results of terminal value calculation in the equity valuation models. It has been shown, that despite a growing body of specialized literature and high-profile research, valuation models appearing in the investment recommendations in Poland may not be built upon in-depth company fundamentals. The paper highlights areas for improvement on the part of the issuers of the recommendations included in the sample and may be successfully used for educational purposes.

\section{References}

Barber, B., Lehavy, R., McNichols, M., Trueman, B. (2001). Can Investors Profit from the Prophets? Security Analyst Recommendations and Stock Returns. The Journal of Finance, 56 (2), 531-563.

Barber, B., Odean. T. (2008). All that glitters: The effect of attention and news on the buying behavior of individual and institutional investors. Review of Financial Studies, 21 (2), 785-818.

Copeland, T., Koller, T., Murrin, J. (1990, 2010). Valuation, Measuring and managing the value of companies. New York: John Wiley \& Sons.

Damodaran, A. (1994). Damodaran on Valuation. New York: John Wiley \& Sons. 
Damodaran, A. (2010). Applied Corporate Finance. Wiley.

Fernandez, P. (2015). Valuation and Common Sense (5th ed.). IESE Business School, University of Navarra. Available at: http://ssrn.com/abstract=2209089.

Fernandez, P., Bilan, A. (2007). 110 Common errors in company valuations. Working Paper No. 714. University of Navarra. IESE Business School.

Green, C. (2006). The Value of Client Access to Analyst Recommendations. Journal of Financial and Quantitative Analysis, 41, 1-24.

Mielcarz, P. (2016). Krótkookresowy wpływ rekomendacji na rynek giełdowy w Polsce. Warszawa: Wydawnictwo Naukowe PWN.

Mielcarz, P., Podgórski B., Weremczuk, P. (2007). Positive Recommendations and Abnormal Returns on the Warsaw Stock Exchange in 2005-2006. In: E. Urbańczyk, The Problems of Company Value Management (pp. 181-190). Lewiston: Publishing House Print Group.

Mielcarz, P., Podgórski, B. (2008). The impact of negative and neutral recommendations on abnormal rates of return on WSE in the years 2005-2006. Studia i Prace Wydziału Nauk Ekonomicznych i Zarzadzania, 7, 533-543.

Mielcarz, P., Roman, E. (2012). Using the idea of market-expected return rates on invested capital in the verification of conformity of market evaluation of stock listed companies with their intrinsic value. Business, Management and Education, 10 (1), 11-24.

Mielcarz, P, Wnuczak, P. (2011). DCF Fair Value Valuation, Excessive Assets and Hidden Inefficiencies. Contemporary Economics, 4, 44-57.

Ross, S., Westerfield, R., Jaffe, J. (2013). Corporate Finance (10th ed.). Business and Economics.

Womack, K. (1996). Do Brokerage Analysts' Recommendations Have Investment Value? The Journal of Finance, 51 (1), 137-167.

Zaremba, A., Konieczka, P. (2015). The Profitability of Following Analyst Recommendations on the Polish Stock Market. E-Finanse, 11 (1), 22-31.

\title{
CO KRYJĄ ZALOŻENIA? BLĘDY METODYCZNE W WYCENACH ANALITYKÓW GIELDOWYCH W POLSCE
}

\begin{abstract}
Streszczenie: Proces wyceny przedsiębiorstw bazuje nie tylko na obiektywnych danych, ale również, ze względu na swoją naturę, odzwierciedla opinie analityków. Pomimo to, zasadnicze znaczenie dla rekomendacji wydawanych przez domy maklerskie ma ich ugruntowanie w teorii ekonomii oraz w istniejących konwencjach metodologicznych. Brak uwzględnienia tych reguł w procesie wyceny może przerodzić nieodłączny element subiektywizmu w pełną arbitralność założeń. Celem niniejszego opracowania jest przedstawienie błędów koncepcyjnych, które mogą pojawić się przy obliczaniu wartości rezydualnej w modelach zdyskontowanych przepływów pieniężnych. W artykule analizujemy kilka postulatów metodycznych oszacowania stopy wzrostu przepływów pieniężnych w okresie rezydualnym. W dalszej części badamy 100 losowo wybranych rekomendacji inwestycyjnych przygotowanych przez analityków domów maklerskich działających w Polsce. Wyniki przeprowadzonych prac wskazują, że postulaty metodologiczne kalkulacji współczynnika wzrostu przepływów w okresie rezydualnym nie są przestrzegane w większości przypadków. Przyjęcie błędnych założeń wejściowych przekłada się na akceptację implikowanych założeń na temat rozwoju spółki, które nie mają ekonomicznego sensu. Te nierealistyczne założenia przygotowywanych wycen mogą kwestionować wiarygodność rekomendacji inwestycyjnych i tworzą podstawy do dyskusji na temat czynników kształtujących decyzje inwestycyjne uczestników rynku.
\end{abstract}

Słowa kluczowe: RONIC; wycena; stopa wzrostu przepływów pieniężnych w okresie rezydualnym; rekomendacje inwestycyjne

\section{Citation}

Mielcarz, P., Osiichuk, D. (2017). What is Behind the Figures? Conceptual Mistakes in the Equity Valuations Prepared by Research Analysts in Poland. Finanse, Rynki Finansowe, Ubezpieczenia, 1 (85), $375-387$. DOI: $10.18276 /$ frfu.2017.1.85-30. 